\title{
Editorial: Excellent Journalism
}

The distinguished school master J.F. Roxburgh, first head master of Stowe, used to require his pupils to write a paragraph or two once a week on a topic of current interest. One of his standard comments on the results was 'Excellent journalism, my dear fellow'.

It was not a compliment. It was, as Evelyn Waugh, one of his pupils, reported, actually the most damning thing he could say: 'trite in thought, colloquial in expression and aiming for effect by smartness and over-statement'. By 'journalism' in this context Roxburgh was referring not to reportage but to the work of the leader writer and opinion former. He actually had a high respect for accurate and lively description of complex events.

In philosophy it is not easy to distinguish between reportage or description and comment or opinion. However it is not difficult to use the methods of excellent journalism in approaching philosophical issues. One may not see much of that sort of thing in journals of academic repute, more perhaps what, in another context, Ruskin referred to as 'mere rotatory motion'. But it may be that in an effort to avoid mere rotatory motion, those inspired to bring philosophy to young people and to those outside academia more generally succumb to the dangers of the journalistic approach.

Philosophy is difficult. At least it is difficult if it is confronting topics such as consciousness, knowledge, truth, metaphysics, God, logic, morality, political principles, human nature and aesthetics. Some feel that these topics have become so recondite that philosophers would be better doing other things. (See Booknotes in this issue and in last January's.) We cannot agree, but a corollary is that we should not fob those to whom we wish to bring philosophy off with the journalistic, or with the glibness and unearned assurance which journalism, but not philosophy, encourages. We should remember Socrates and remember that when it comes to the philosophical, whatever we think we know, we do not know, or do not know enough to know that we know. 